\title{
EXPLORING RELIGIOUS REPRESENTATIONS IN PROFESSIONAL COMMUNICATION
}

\author{
Luminița Todea, Ramona Demarcsek \\ Technical University of Cluj-Napoca \\ North University Centre of Baia Mare, Romania
}

\begin{abstract}
This paper aims at analysing the way in which specific religious concepts function as memorable and flexible names for future growth in professional communication. The corpus consists of examples selected from the language of business and technology which imply religious or mythological connotations such as: angel eyes, avatar, Daemon tools, icon, Kali Linux, Trojan etc. Each of these names was carefully selected in order to reveal connotations that reflect a deeper understanding of specific brands. Brand names and company names could be discussed in terms of live metaphors because they provide a mental image that shapes our understanding and have the potential to recreate reality by highlighting new connections and displaying particular associations.
\end{abstract}

Keywords: professional communication, angel naming, brand names, company names.

\section{Introduction}

The main purposes of our paper are to identify and discuss how specific religious concepts function as memorable and flexible names for future growth in professional communication in international as well as Romanian context. Examples that imply religious or mythological significance are carefully selected from the field of business and technology. Brand/company names and names of devices used in Business and Computer Science are used to illustrate examples of words with religious connotation that are used metaphorically by corporations in order to suggest certain effects.

\section{Brand names and globalisation}

The practice of using real words in a suggestive manner became common between the 1970s and 1990s; therefore it has become very frequent during the Internet boom of the 1990s. The use of real words in an arbitrary way was chosen with "the intention of communicating a set of associations that reflected the essence of these nascent brands" (Ind 2013: 201). They "provide a mental image that shapes our understanding and have the potential to re-describe reality by revealing new connections and hinting at hidden meanings" (Ind 2013: 202). "Meanings are not hidden in people's heads, but occur out in the ceaseless flow of living language-interwoven relations between ourselves and the other and otherness around us" (Shotter 2005: 130). For example, the 
name Argonaut Information Systems was used metaphorically to convey the notion that the accounts payable software would perform heroically for end-users, while the name Oracle Database suggests that the company would provide information upon request.

It is common knowledge that English has become the universal language of business and technology. As David Crystal (1998: 70) states, "globalization processes have never been so marked; communication and transport technologies have never been so omnipresent; there has never been so much language contact; and no language has ever exercised so much international influence as English." Therefore, one should agree that English is a global language; and "choosing it as the language of a commercial name is a statement for the international and multilingual use of the name" (Sjoblom 2013: 5). Words that are similar in many languages, the so-called internationalisms, are linguistic features that make commercial names to function properly at a global level.

From a grammatical perspective, brand names belong to the category of proper names, "having a special status at the semantic level, that of not marking concordance in gender or number" (Martin 2013: 303). Product names belong to the category of ergonyms, which are names for objects created by people, but they are regarded as broader terms for commercial names (Heegen 2013: 320). Their symbolic value is given by the consumers' comprehension of the connotative value of the notion with which they are associated. In addition to conveying information, brand names function at an emotional level because they can inspire the formation of an emotional attitude towards the specific product. On one hand, a brand name is defined as a "product name that is designed to convey a specific image with which consumers can identify or relate to" (Danesi 2009: 47). On the other hand, it is regarded as a logical construct, evoking an unconscious system of thought, based on "a poetic sense of the meaning nuances built into words" (Danesi 2009: 182).

\section{Defining angel as a concept}

Our main focus is the concept angel and the way in which this term is assimilated and illustrated mostly in a professional context.

According to the definition provided by dictionaries, there is a wide range of explanations concerning the word angel (etymology: Latin angelus, Greek angelos 'messenger'). Firstly, an angel is a typically benevolent celestial being that acts as an intermediary between heaven and earth, especially in Christianity, Judaism, Islam, and Zoroastrianism; a representation of such a being, especially in Christianity, conventionally in the image of a human figure with a halo and wings. While a guardian angel is an angel that is assigned to protect and guide a particular person, group, kingdom, or country, a fallen angel is one that has rebelled against God and has been subsequently cast out of heaven. The Bible describes Lucifer as having become a fallen angel after he desired to become God rather than be a servant of God. For instance, Hells Angels is the name of a gang of male motorcycle enthusiasts, first formed in California in 1948 and originally notorious for lawless behaviour. The name Blue Angels is attributed to the 
U.S. Navy fighter aircraft squadron that stages aerobatic performances at air shows and other events throughout the United States and around the world.

Secondly, the word angel refers to people in different circumstances. For instance, an angel is a person of exemplary conduct or virtue, e.g. Their parents think they are angels; a woman who is completely devoted to her husband and family is named in an ironic way the angel in the house. It can also be used in similes or comparisons to refer to a person's outstanding beauty or qualities, e.g. She sang like an angel; in approval to a person who is kind or helpful, e.g. Be an angel and help us with our luggage; or as a term of endearment, e.g. I miss you too, angel. The expression on the side of the angels is equivalent to 'on the side of what is right'. Angel's advocate is one who looks for and argues in support of the positive aspects and benefits of a certain argument, whether or not he or she believes them to be true (the opposite of a devil's advocate), while enough to make the angels weep is an expression for a terrible, distressing situation or sequence of events, as to shake the foundations of one's faith or hope. The saying Fools rush in where angels fear to tread implies that ignorant or inexperienced individuals get involved in situations that wiser persons would avoid.

Thirdly, from a historical perspective, an angel is a former English coin minted between the reigns of Edward IV and Charles I and bearing the figure of the archangel Michael killing a dragon. The reverse of the coin represents a ship with a cross in front of the mast. In the 16th century the angel became the piece given to those touched by king's evil (tuberculosis) in the belief that the king's touch could cure the disease.

In technology, in an informal way, angels refer to aircraft's altitude, often used with a numeral indicating thousand of feet, e.g. we rendezvous at angels nine or an unexplained radar echo. At the same time, a type of building insulation made of spun glass is named angel hair.

In business, an angel is used to name a financial backer of an enterprise, especially a dramatic production or a political campaign such as an affluent individual who provides capital for a startup, usually in exchange for convertible debt or ownership equity in business. The term angel in angel investor, business angel or angel funder originally comes from Broadway theatre, where it was used to describe wealthy individuals who provided money for theatrical productions that would otherwise have had to shut down. Angel investors organize themselves into angel groups or angel networks. In terms of exemplifying this context, we refer to the companies Fashion Angel (https://fashion-angel.co.uk/), Angels Den (https://www.angelsden.com/) and Tech Coast Angels (https://www.techcoastangels.com/), which have the most key elements of successful business (connections, knowledge and empowerment for entrepreneurs) and offer mentoring, business support and access to funding for different types of industries. Another example is the UK Business Angels Association which acts as the voice of the angel investment community and strives to build and connect the early-stage investment ecosystem, thus being the UK national trade association representing angel and early-stage investment. According to Farlex Financial Dictionary (2012) a fallen angel is the definition for a stock or bond that has drastically declined in value; a company or 
organization that was previously successful, but is currently failing. In both cases, fallen angels may be undervalued or it implies bad investments nearing bankruptcy. This makes investing in a fallen angel very risky, but it has the possibility of a high return. The phrase oil of angels refers to money, particularly when used as bribe. Furthermore, angel dusting is a misleading marketing practice of including a minuscule amount of an active ingredient in a cosmetic/dietary supplement or food product, but it is insufficient to give any measurable benefit.

\section{Angel naming for international brands and companies}

Company names belong to the class of ergonyms (etymology: Greek ergon 'work, product'). Considering Fahlbusch's opinion (2011), company names must be distinctive not misleading, and they should evoke positive associations. They are defined as "the proper names of legally independent entities seeking to deliver a sustainable and profitable performance in the form of an adequate return on capital employed" (Fahlbusch 2011: 187). They also display certain features, such as amplification of international connotation and sonority, importance of specific graphemic characteristics, length diminishing, and reduction of transparency. The development towards simpler, more concise forms appears to be driven by their ease of use in Internet addresses and company logos. Internet addresses have to be short so that every user can remember and type them easily without making any errors. According to Sjoblom (2008), the multimodality in communication for company names implies that "interpretations are provided not only by linguistic elements (writing and speaking) but also by other semiotic modes, e.g. image, sound and movement, which all are linked together in a socio-cultural context" (Sjoblom 2008: 351).

One of the aims of the present paper is to discuss the linguistic and extra-linguistic factors in the creation of the selected ergonyms. The main criteria for the analysis are language choices, semantic structures, and pragmatic meanings. The web homepages for the respective companies, institutions or organisations were studied providing relevant information about them etc. Considering the relationship between the name used in the ergonym and the denoted association of meanings, their usage may be: denotative, if the word used in the ergonym has a direct, real connection to the area of work of the respective company, such as demonstrating the purpose and specific activities; or connotative in case of a metaphorical or symbolic connection. These are mainly related to a positive connotation, an emotionally subjective evaluation as a form of endearment.

The following part highlights a selection of brand names that include the word angel: Angel, a perfume by Thierry Mugler; Angel Natural Eyelashes; Invicta Angel Women Watches; Tangle Angel Hair Brush; Angel Juicer, a juice extractor - the name of the device implies that customers can benefit from the gift of healthy life if they use this particular product; Angel Soft, a brand of toilet paper; Angel-in-us Coffee, a coffee shop brand; Angel City Brewery, Los Angeles, USA. Angelic Bakehouse is, according to the name, a brand that reflects purity of the ingredients and the processes used in 
making their products. Angels is also one of Victoria's Secrets lingerie lines. The term Angel has also become synonymous with being a contracted spokesmodel for the brand. Angelcare Movement and Sound is a baby movement and sound monitor; the company slogan Angelcare bringing you peace of mind implies protection provided by guardian angels. The Child Angel wrist band is one of the smallest and most advanced child tracking devices that works with a mobile phone in order to give parents an accurate location for their child, including a variety of devices such as those called Pet Angel, Care Angel, and School Angel. According to their official statement, Looking after your loved ones, the connotative meaning of the notion angel suggests vigilance and care. Angel Eyes or halo headlights are automotive front lighting units with luminous rings inside the headlight assembly. Consequently, these names are enriched semantically by means of new connotations.

The section below includes a selection of international companies (and their websites) that include the word angel in their name:

- Angel Apparel (www.angelapparel.com) is an online shop for clothes which implies that "A signature look from ANGEL doesn't just make an outfit, it makes a lasting impression".

- Angel Brand (www.angelbrand.com) is an online shop for spices, herbs and teas.

- Angel Clothing (www.kinkyangel.co.uk) is an online alternative, steampunk and gothic clothing super store.

- Angel Dear (www.angeldear.net) creates classic baby clothing and accessories; "the ultimate in softness".

- Angel's Envy (www.angelsenvy.com) advertises and commercialises Kentucky Bourbon.

- Angel's Face (www.angels-face.co.uk) sells quality clothing for girls.

- Angels Jeans (www.angelsjeans.com) - Forever Young - "creates on-trend and affordable jeans with an emphasis on fit".

- Fashion Angels (www.fashionangels.com) is a leading designer and manufacturer of teen girls' lifestyle and activity products. Therefore, it should empower teenage girls: "Find Your Talents. Find Your Style. Find your wings!"

- Guardian Angels (www.guardianangels.org) is a non-profit safety patrol organisation, located in New York, USA.

- Lisa Angel (www.lisaangel.co.uk) offers a selection of high-quality men's and women's fashion jewellery. In this instance, the word angel might be associated with a proper noun, a surname, and not with a common noun.

- Super Angel Juicers (www.superangeljuicers.com) should add quality to people's daily habits for enjoying a happy life.

- Tangle Angel (www.tangleangel.com) is a UK-based company that sells professional hairbrushes, including a variety of products such as: Tangle Angel Classic or Compact, Tangle Cherub, Shine Angel, Pet Angel, Tangle Angel Baby key-ring brushes etc. 


\section{A formal classification of Romanian company names including the term angel}

One of the purposes of our paper is to discuss and illustrate how different names of Romanian commercial companies, firms or organisations have included the word angel in their naming. At a formal level, most of them consist of more than one word. The naming patterns are classified according to their syntactic and morphological characteristics. They display a concise form and achieve a relatively high level of awareness. The following taxonomy is based on the syntactic structure of this particular category of Romanian company names including the common noun angel:

1 . noun phrase with modifier(s) in anteposition

1.1. noun phrase with a modifier placed in anteposition, adjective + common noun (sg.): e.g. Blue Angel, Dark Angel, Dear Angel, Guardian Angel (insurance company), Little Angel, Lost Angel, Purple Angels, Yellow Angel (a road assistance, mostly car towing firm that implies a Romanian adoption and adaptation of an international business content and naming of a similar German or American company) etc; or numeral + common noun (pl.), e.g. Two Angels.

1.2. noun phrase with two modifiers in anteposition: e.g. Extremo Beautiful Angel SRL (a company categorized under Metal Production and Processing), Happy Little Angels. The structures Larry Little Angel or Daria Little Angel consist of proper noun (first name) + adjective + common noun.

1.3. noun phrase with two or more modifiers in postposition, such as Angel Beauty Salon SRL, a company categorized under Food Processing and Beverage Production.

2. noun phrase with a modifier placed in postposition in a singular or a plural form: e.g. Angel Company (a business in the flooring and floor covering contractors industry, dealing with the import and distribution of ceramic tiles); Angels Distributions, Angels Mannequins, and Angel Wings are retail companies; Angel Kids, a kindergarten; or genitive structures in Angel's Home, Angel's Path (a firm dealing with funeral services), Angels' Flowers, and Angels' Land (a firm recorded under Beauty and Personal Care).

3. noun phrases including a premodifier + common noun + postmodifier, e.g. The White Angel Store, a retail business.

4. noun phrases that include more than two nouns and other modifiers, in addition to the common noun angel: An Angel for Angels Association (an organization for helping people in need), Angel and Demon Promotion (advertising company), Angels' Garden Flower Shop, Our Angel's Funeral House (an organization in funeral service and cremation industry).

5. hybrid constructions or blended words: for instance, Angelmed, the name of a company in the field of medicine, is a combination of two common nouns, angel + medicine. 


\section{Definitions of computer science concepts with counterpart representation in religion or mythology}

An avatar is a digital representation of a person or being. It can often take on any of various forms as a participant chooses, i.e. 3D, animated, photo, sketch etc. In religion, it represents the descent of a deity to earth, and its incarnation as a man or an animal (chiefly associated with the incarnations of Vishnu in Hinduism). Etymology: Sanskrit avatärah 'descent of a deity from heaven', avatar - compound noun from ava ('down') + tarati ('he crosses').

Daemon/Demon is a computer program that runs by itself directly under the operating system. A demon is part of a larger application program. Demon is often used equivalently to Daemon, especially in the Unix world. Traditionally, the process names of a daemon end with the letter $d$, for clarification that the process is, in fact, a daemon, and for differentiation between a daemon and a normal computer program. The term was coined by the programmers of MIT's Project MAC. They took the name from Maxwell's demon, an imaginary being from a thought experiment that constantly works in the background, sorting molecules. In the philosophy of thermal and statistical physics, Maxwell's demon is a thought experiment created by the physicist James Clerk Maxwell, in which he suggested how the second law of thermodynamics might hypothetically be violated. In the thought experiment, a demon controls a small door between two chambers of gas. As individual gas molecules approach the door, the demon quickly opens and shuts the door so that fast molecules pass into the other chamber, while slow molecules remain in the first chamber. Maxwell's Demon is consistent with Greek mythology's interpretation of a daemon as a supernatural being working in the background, with no particular bias towards good or evil. In his letters and books, Maxwell described the agent opening the door between the chambers as a "finite being". William Thomson, Lord Kelvin, was the first to use the word demon for Maxwell's concept, in the journal Nature in 1874, and implied that he intended the mediating rather than malevolent connotation of the word.

A halo is a circular band of colored light around a light source, as around the sun or moon, caused by the refraction and reflection of light by ice particles suspended in the intervening atmosphere. It can also be a cloud of gas and other matter surrounding and captured by the gravitational field of a large diffuse astronomical object, such as a galaxy or cluster of galaxies. As a religious representation, it represents a luminous ring or disk of light surrounding the heads or bodies of sacred figures, such as saints, in religious paintings; a nimbus. Etymology: Latin halos, Ancient Greek hálōs 'disk of the sun or moon, ring of light around the sun or moon'.

An icon is a picture on a screen that represents a specific file, directory, window, option, or program in Computer Science. Computing meaning was first recorded in 1982. It is defined as a religious representation or picture of a sacred or sanctified Christian personage, traditionally used and venerated in the Eastern Church. Eastern Orthodox Church meaning is attested from 1833. Etymology: Latin icon, Ancient Greek eikōn 'likeness, image, portrait'. 
A host is a computer containing data or programs that another computer can access by means of a network or modem in Computer Science. Considering the religious significance, it represents sacramental bread - Communion bread, the Lamb or simply the host, is the bread which is used in the Christian ritual of the Eucharist. A multitude of people arrayed as an army is also used in religious sense, as Heavenly host (of angels). Etymology: Latin hostia 'sacrificial victim'.

Kali Linux is an advanced penetration testing platform. It contains several hundred tools which are geared towards various information security tasks. As a religious representation it refers to the Hindu goddess of time, creation, destruction and power, the Divine Mother, Mother of the Universe.

Oracle Database is an object-relational database management system produced and marketed by Oracle Corporation (commonly referred to as Oracle RDBMS or simply as $\mathrm{Oracle}$ ). In classical antiquity, an oracle was a person or agency considered to provide wise and insightful counsel or prophetic predictions or precognition of the future, inspired by the gods - a form of divination. In the Bible, it represents the sanctuary of a Temple. Etymology: Latin ōrāre 'to speak'.

A server is a computer or a program which provides services to other programs or users, either in the same computer or over a computer network. It can be found in different structures such as nouns or noun phrases; e.g. server, a server name, a server parameter, a server development platform etc. In the Roman Catholic and Anglican churches, the server is an attendant on the priest at a low celebration of the eucharist, who helps the priest to vest and unvest, arranges the service book, lights and extinguishes the altar lights, places the elements on the credence and brings them to the priest, and ministers in other ways. The server is usually a boy or another layman, and represents the priest's assistants and the choir at a high celebration. Etymology: serve (verb) + -er (suffix); Latin servire 'to serve'.

A Trojan horse/Trojan is any malicious computer program which misleads users of its true intent. Trojans may allow an attacker to access users' personal information such as banking information, passwords, or personal identity. The computer virus meaning is attested by 1982. The term is derived from the Ancient Greek story of the deceptive wooden horse that led to the fall of the city of Troy. Trojan horse was figurative of ambush-from-within in Roman times. It was attested in English from 1570s. In early modern English, it means 'a determined fellow, one who fights or works hard' from the Trojans' long resistance to the Greeks in the Trojan War.

\section{Conclusions}

These names have been chosen with the intention of communicating certain associations that reflect their essence. In this respect, brand names and company names are live metaphors because they provide a mental network that shapes our understanding and imagination; therefore one can say that they have the potential to redescribe reality by suggesting new connections and displaying hidden meanings. 


\section{References}

Crystal, D. 1998. English as a Global Language. Cambridge: Cambridge University Press.

Danesi, M. 2009. Dictionary of Media and Communications. Armonk, New York: M. E. Sharpe.

Fahlbusch, F. 2013. Abbreviations tendencies in company names deriving from internet addresses and logos. In Names in the Economy: Cultural Prospects, P. Sjoblom, T. Ainiala, and U. Hakala (eds.), 186-200. Newcastle upon Tyne: Cambridge Scholars Publishing.

Felecan, O. 2008. Names of Romanian institutions after 1989. In I nomi nel tempo e nello spazio. Atti del XXII Congresso Internazionale di Scienze Onomastiche, Pisa 28 agosto-4settembre, 2005, vol.II: Onomastica e Societa, M.G. Arcamone, D. Bremer, D. De Camilli and B. Porcelli (eds.), 579-594. Pisa: Edizioni ETS.

Heegen, D. 2013. An extended typology for product names: examples from yoghurt names of the German and Swedish market. In Names in the Economy: Cultural Prospects, P. Sjoblom, T. Ainiala, and U. Hakala (eds.), 311-331. Newcastle upon Tyne: Cambridge Scholars Publishing.

Ind, N. 2013. The co-creation of brand names. In Names in the Economy: Cultural Prospects, P. Sjoblom, T. Ainiala, and U. Hakala (eds.), 201-213. Newcastle upon Tyne: Cambridge Scholars Publishing.

Martin, M. 2013. From car brands to their legends. In Names in the Economy: Cultural Prospects, P. Sjoblom, T. Ainiala, and U. Hakala (eds.), 300-310. Newcastle upon Tyne: Cambridge Scholars Publishing.

Shotter, J. 2005. Peripheral Vision. Organization Studies 26 (1): 113-135.

Sjoblom, P. 2008. Multimodality of Company Names. Onoma 43: 351-380.

Sjoblom, P. 2013. Lumia by Nokia, Iphone by Apple: global or local features in commercial names? In Names in the Economy: Cultural Prospects, P. Sjoblom, T. Ainiala, and U. Hakala (eds.), 2-14. Newcastle upon Tyne: Cambridge Scholars Publishing.

\section{Websites (accessed in September 2017)}

https://financial-dictionary.thefreedictionary.com

www.britannica.com

www.dictionary.com

www.dictionary.cambridge.org

www.etymonline.com

www.listafirme.ro

www.oxforddictionaries.com

www.techterms.com 